\title{
Evaluation of Health Care Services Delivered to Syrian Refugees in a Tertiary Pediatrics Hospital Between 2013-2016
}

Bir Üçüncü Basamak Çocuk Sağlı̆̆ı ve Hastalıkları Hastanesinde 2013-2016 Y1lları Arasında Suriyeli Sığınmacilara Sunulan Sağlık Hizmetlerinin

Değerlendirilmesi

Ali Güngör ${ }^{1}$, Alkım Öden Akman ${ }^{1}$ Cüneyt Karagöl ${ }^{1}$, Mücahit Koçoğlư ${ }^{1}$, Bahar Çuhacı Çakır², İlker Çetin ${ }^{3}$, Halil İbrahim Yakut ${ }^{1}$

${ }^{1}$ Department of Pediatrics, University of Health Sciences, Ankara Child Health and Diseases Hematology Oncology Training and Research Hospital, Ankara, TURKEY.

${ }^{2}$ Department of Social Pediatrics, University of Health Sciences, Ankara Child Health and Diseases Hematology Oncology Training and Research Hospital, Ankara

${ }^{3}$ Department of Pediatric Cardiology, University of Health Sciences, Ankara Child Health and Diseases Hematology Oncology Training and Research Hospital, Ankara, TURKEY

Yazışma Adresi / Correspondence:

Ali Güngör

Sağlık Bilimleri Üniversitesi Ankara Çocuk Sağlığı ve Hastalıkları Hematoloji Onkoloji Eğitim ve Araştırma Hastanesi, Ankara, Turkey T: +903125960000 E-mail: gungorali19@gmail.com

Geliş Tarihi / Received : 29.01.2019 Kabul Tarihi / Accepted : 04.03.2019

\footnotetext{
Abstract

Objective Millions of Syrian had to abandon their country due to the civil war and took refugee in neighboring countries. This refugee crisis is affecting the countries that accept immigrants in terms of health care service, economical, political and social issues. We aim to evaluate, density of the Syrian refugees in outpatient and emergency services, inpatient services, specific interventions, and investigations ordered between 2013 and 2016. ( Sakarya Med J 2019, 9(1):46-51 )

Materials We tried to determine density of Syrian refugees among the patients who presented to the emergency department and outpatient clinics and the patients hospitalized in and Methods our hospital between 2013 and 2016. It was tried to determine the density of Syrian patients among the interventional procedures and specific investigations ordered in the pediatric sub-branches.

Results Approximately 13,538 Syrian refugees presented to our hospital for examination, investigations and treatment between 2013 and 2016 . The number of Syrian refugees who presented to our hospital increased to 8,540 in 2016 from 265 in 2013. The percentage of Syrian refugees in the ECG, Cerebral MRI and CT, Rhythm Holter and EEG tests and the number of Syrian refugees in the total number has increased over the years over the years 2013-2016. The rate of Syrian refugees involved in the hospital invoice raised to $6.63 \%$ in 2016 from $1.05 \%$ in 2013 .

Conclusion The crisis in Syria affects neighboring countries in many issues. Countries like Turkey which accept a large number of refugees should rearrange their health policies considering refugees. Further multicenter studies are needed to determine the impact of this immigration on health care system.

Keywords refugee; child; Health Care Services
}

Amaç Suriye’de baslayan ic savas sebebiyle milyonlarca Suriyeli ülkesini terk ederek komsu ülkelere sı̆̆ınmıstır. Yasanan bu sı̆̆ınmacı krizi göc alan ülkeleri sağllk ve bakım hizmetleri, ekonomik, siyasi ve toplumsal birçok konuda etkilemektedir. Bu çalıșmada hastanemizde 2013-2016 ylları arasinda verilen poliklinik ve acil servis hizmeti, yatan hasta hizmeti, yapılan özellikli girişimler ile istenilen tetkiklerdeki Suriyeli sı̆̆ı̆macı yoğunluğu belirlenmeye çalışılmıștı. ( Sakarya Tip Dergisi 2019, 9(1):46-51 ).

Gereçve 2013-2016 yılları arasında hastanemiz acil servisi ve polikliniklere bașvuran hastalar ile hastanemizde yatarak tedavi gören tüm hastalar içindeki Suriveli sı̆̆ınmacı yoğunluğu belirlenmeye

Yöntems çalşsldd. Hastanemizdeki pediatri yandallarında yapılan girişimsel işslemler ve özellikli tetkiklerdeki Suriyeli hastaların yoğunluğunu belirlemeye çalışldı.

Bulgular 2013-2016 yılları arasında hastanemize yaklaşık olarak 13538 Suriyeli sığınmacı muayene, tetkik ve tedavi amactyla başvurmuştur. 2013 yllinda hastanemize başvuran Suriyeli stğı̆nmacı sayısı 265 iken 2016 yllnda bu rakam 8540'a yükselmistir. 2013-2016 yllar arasinda hastanemizde yapılan ÖGD, KİA ve karaciğer bivopsisi ile EKO, Beyin MRG ve BT, Ritim holter ve EEG tetkiklerindeki Suriyeli sı̆̆ınmacı sayısı ve toplam sayı içindeki Suriyeli sı̆̆ınmacı yüzdesi yıllar içinde giderek artmıştır. 2013 yılinda hastane faturasındaki Suriyeli sı̆̆ınmacı oranı \% 1,05 iken 2016 yılinda bu oran \% 6,63'e yükselmiştir.

Sonuç Suriye’de yașanan kriz komșu ülkeleri birçok konuda etkilemektedir. Türkiye gibi fazla sayıda mülteci kabul eden ülkelerin sağllk politikalarını sı̆̆ımacıları göz ününde tutarak yeniden düzenlemesi gerekmektedir. Yașanan bu göçün sağlık sistemi üzerine etkisini görmek için çok merkezli çalıșmalara ihtiyaç vardır. 


\section{INTRODUCTION}

Millions of Syrian had to abandon their country due to the civil war that began in Syria in 2011. According to the United Nations data, 4 to 6 million Syrians have abandoned their country since 2011. ${ }^{1,2}$ The Syrian people who escaped from the conflicts have taken refugee, especially in Turkey; Lebanon, Jordan, Iraq and other neighboring countries. Turkey has declared to implement an "open door policy" for Syrian refugees and embraced the aggrieved people shortly after the civil war began. ${ }^{2-4}$ According to data of the United Nations High Commissioner for Refugees, Turkey is the country which harbors the largest number of Syrian refugees. ${ }^{2}$

This refugee crisis affects many countries, especially the countries that accept refugees, in terms of many health and care services, economic, political and social issues. Providing adequate health care services for refugees is a challenging issue for these countries in terms of economy and workload. Turkey, Lebanon and Jordan are the leading countries affected by this situation. ${ }^{4-8}$ Currently, $25 \%$ of the Lebanese population consists of Syrian refugees, and this crisis is now called the Syrian-Lebanese crisis in Lebanon. ${ }^{8,9}$

The protection provided to the Syrians who took refugee in our country is the Temporary Protection according to the international literature. ${ }^{10,11}$ The Syrians who are taken to the status of "foreigners under temporary protection" by issuing and registering their ID card (foreign identification document) can benefit from several services including healthcare, education, temporary shelter and social aid. ${ }^{12}$ Our country hosts more than 3 million Syrian refugees as of today, and it is known that so far, 25.919.750 outpatient services, 1.143 .393 inpatient services, and 953.466 surgeries were carried out for the Syrian and Iraqi refugees. This increases both the health care costs of our country, and the workload of health workers. ${ }^{12-14}$

More than half of the Syrian population that has migra- ted out of the country consists of women and children. ${ }^{3,15}$ Children are naturally the most affected by migration and war. While refugee children are exposed to many traumas such as war, violence, seperation from family and abuse on one hand, their health is negatively affected and threatened by long-term migratory journeys, poor and inadequate nutrition, conditions with lack of hygiene and being deprived from preventive health services. ${ }^{15-18}$

The aim of this study was to evaluate the prevalence of Syrian refugees in outpatient and emergency services, inpatient services, special interventions and the investigations ordered between 2013-2016.

\section{MATERIAL and METHOD}

This study was conducted as a descriptive cross-sectional study to determine the density of Syrian refugees among the total presentations in a tertiary pediatric hospital. All patients who presented to the emergency department and outpatient clinics of our hospital between 2013 and 2016 were scanned through the registration system, and the density of Syrian refugees among the total presentations was tried to be determined. The number of patients hospitalized and treated in the inpatient services of our hospital between the same dates was determined and the density of the Syrian refugees among these patients was investigated. Among the interventional procedures and specific investigations ordered in the pediatric sub-branches between 2013 and 2016; the numbers of cerebral magnetic resonance imaging (MRI) and computed tomography (CT), electroencephalography (EEG), esophagogastroduodenoscopy (EGD), rhythm holter, echocardiography (ECO), bone marrow aspiration (BMA), bone marrow biopsy and liver biopsy were determined. We tried to determine the density of Syrian patients in these investigations and procedures. This study was approved by University of Health Sciences, Ankara Child Health and Diseases Hematology Oncology Training and Research Hospital Institutional Review Board (12/09/2017-28). 
Statistical Analysis: The descriptive categorical variables are expressed as number (n) and percentage (\%). The results were evaluated using the 'Statistical Package for Social Sciences - SPSS 17’' (Chicago, USA) software.

\section{RESULTS}

Approximately 2.200.478 patients admitted to the emergency department and outpatient clinics of our hospital for examination, investigations and treatment between 2013 and 2016. About 13.538 (0.62\%) of these patients were Syrian refugees. Of Syrian refugees, $30.9 \%$ presented to the emergency department and $69.1 \%$ to the outpatient clinics. Approximately 68.000 patients have been hospitalized in the inpatient clinics of our hospital with $0.82(n=555)$ of them being Syrian refugees. The number of Syrian refugees who presented to our hospital increased to 8540 in 2016 from 265 in 2013. Likewise, the number of Syrian refugees hospitalized in the inpatient services of our hospital raised to 492 in 2016 from 11 in 2013. A significant increase was found both in the number of Syrian patients who presented to our hospital, and the number of Syrian patients hospitalized in our hospital between 2013 and 2016. The number and rate of Syrian refugees' presentations to our hospital between 2013-2016 are shown in Table 1 .

Among the interventional procedures performed between 2013 and 2016 in pediatric sub-branches of our hospital; when the distribution of EGD, BMA, BMB and liver biopsy was examined, it was found that the number of Syrian refugees increased especially in 2015 and 2016. The distribution of Syrian refugees by the interventional procedures performed, and years is given in Table 2 .

Among the procedures performed and investigations ordered between 2013 and 2016 in our hospital; cerebral MRI and CT, routine and sleep-activated EEG, rhythm holter, and echocardiography were included in this study. The number and rate of Syrian refugees in these procedures and investigations gradually increased between 2013 and 2016. While ECO was performed in 13 Syrian refugees in 2013, this number increased to 156 in 2016, and similarly the number of MRIs ordered for Syrian refugees raised to 128 in 2016 from only one in 2013. Table 3 shows the changes in the number and rate of Syrian refugees in

\begin{tabular}{|l|c|c|c|c|c|c|c|c|}
\hline \multicolumn{2}{|l|}{ Table 1. The number and rate of Syrian refugees' presentations to our hospital between 2013-2016 } \\
\hline $\begin{array}{l}\text { Syrian } \\
\text { Refugees }\end{array}$ & \multicolumn{2}{|c|}{ Total number of patients } & \multicolumn{2}{c|}{$\begin{array}{c}\text { Number of emergency } \\
\text { service admission }\end{array}$} & \multicolumn{2}{c|}{$\begin{array}{c}\text { Number of Polyclinic } \\
\text { admission }\end{array}$} & \multicolumn{2}{c|}{ Number of Inpatients } \\
\hline & $\mathrm{n}$ & $\%$ & $\mathrm{n}$ & $\%$ & $\mathrm{n}$ & $\%$ & $\mathrm{n}$ & $\%$ \\
\hline 2013 & 265 & 0.06 & 73 & 0.06 & 192 & 0.06 & 11 & 0.08 \\
\hline 2014 & 1297 & 0.23 & 493 & 0.40 & 804 & 0.19 & 5 & 0.03 \\
\hline 2015 & 3436 & 0.59 & 1235 & 0.92 & 2201 & 0.49 & 47 & 0.27 \\
\hline 2016 & 8540 & 1.42 & 2380 & 1.72 & 6160 & 1.33 & 492 & 2.82 \\
\hline
\end{tabular}

\begin{tabular}{|c|c|c|c|c|c|c|c|c|}
\hline \multirow[t]{2}{*}{$\begin{array}{l}\text { Syrian } \\
\text { Refugees }\end{array}$} & \multicolumn{2}{|c|}{$\begin{array}{l}\text { Esophagogastroduoden- } \\
\text { oscopy }\end{array}$} & \multicolumn{2}{|c|}{ Bone marrow aspiration } & \multicolumn{2}{|c|}{ Bone marrow biopsy } & \multicolumn{2}{|c|}{ Liver biopsy } \\
\hline & $\mathrm{n}$ & $\%$ & $\mathrm{n}$ & $\%$ & $\mathrm{n}$ & $\%$ & $\mathrm{n}$ & $\%$ \\
\hline 2013 & - & - & 8 & 2.20 & 2 & 4 & - & - \\
\hline 2014 & - & - & 8 & 2.52 & 2 & 3.28 & 1 & 2.56 \\
\hline 2015 & 4 & 0.57 & 15 & 4.27 & 5 & 5.81 & 4 & 7.84 \\
\hline 2016 & 12 & 1.61 & 33 & 8.44 & 2 & 2.47 & 4 & 6.67 \\
\hline
\end{tabular}


Sakarya Med J 2019;9(1):46-51

GÜNGÖR et al. Evaluation of Health Services Delivered to Refugees

\begin{tabular}{|c|c|c|c|c|c|c|}
\hline Syrian refugees & $\mathrm{ECO}$ & Rhythm Holter & Routine EEG & Sleep Act. EEG & Cerebral CT & Cerebral MRI \\
\hline & $\mathrm{n}(\%)$ & $\mathrm{n}(\%)$ & $\mathrm{n}(\%)$ & $\mathrm{n}(\%)$ & $\mathrm{n}(\%)$ & $\mathrm{n}(\%)$ \\
\hline 2013 & $13(0.10)$ & - & $1(0.03)$ & - & $1(3.85)$ & $1(0.03)$ \\
\hline 2014 & $43(0.36)$ & $2(0.13)$ & $11(0.24)$ & - & $2(7.69)$ & $14(0.27)$ \\
\hline 2015 & $86(0.76)$ & $5(0.34)$ & $16(0.51)$ & $28(0.73)$ & $7(9.72)$ & $41(0.92)$ \\
\hline 2016 & $156(1.2)$ & $5(0.36)$ & $64(1.47)$ & $91(1.92)$ & $11(11)$ & $128(2.94)$ \\
\hline
\end{tabular}

the investigations by years.

\section{DISCUSSION}

The total amount of invoices reported to the Social Security Institution by our hospital between 2013 and 2016 was approximately 221.551.752 Turkish liras (TL) (89.988.526 United States Dollar (USD)], with about 8.605.083 TL (3.495.159 USD) (3.88\%) of this amount covered the health care services delivered to the Syrian refugees. The share of Syrian refugees in the annual invoice was $1.05 \%$ in 2013, while this rate increased to $6.63 \%$ in 2016. Similarly, health care costs for the Syrian refugees increased to approximately 4.260.110 TL (1.407.370 USD) in 2016 from about 465.865 TL (244.420 USD) in 2013. The costs of health care services that were delivered to the Syrian refugees increased over years, both in price and rate (Figure 1).
Millions of Syrian abandoned their country and took refuge in neighboring countries due to the civil war, which began in Syria. This migration that started in 2011, becomes gradually influential in countries that accept the refugees. Turkey, Lebanon and Jordan are the leading countries that host the largest number of refugees. One of the most important problems faced by countries that accept the refugees is health care services provided to the refugees. ${ }^{3,6,9} \mathrm{In}$ a study conducted in Jordan, it was reported that the total expenditure of the Jordanian Ministry of Health for Syrian refugees between January 2013 and April 2013 was approximately 53 million USD, of which only 5 million USD of this amount was covered by the United Nations. This

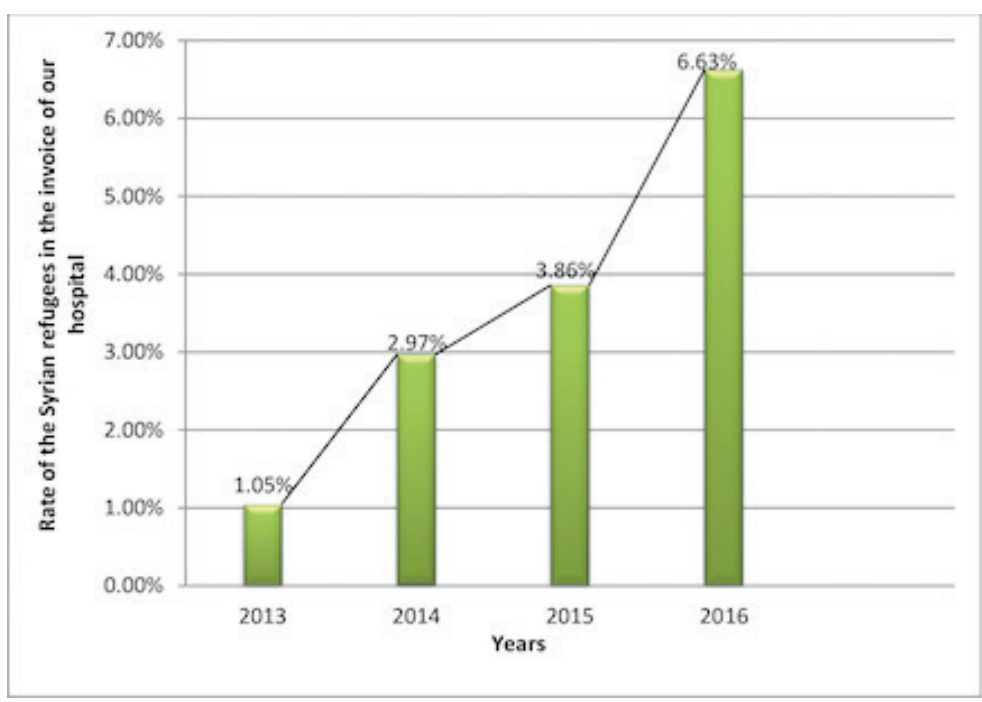

Figure 1. Change in the share of Syrian refugees in the invoice of our hospital between 2013 and 2016 
negatively affected the budget of the Jordanian Ministry of Health, thus Jordanian economy. ${ }^{6}$ Likewise, Syrian refugees, who make up $25 \%$ of the Lebanese population, are adversely affecting economy and health care system of Lebanon. ${ }^{8,9}$ Our country has accepted the largest number of Syrian refugees. While the expenditure for Syrian refugees between April 2011 and November 2014 was 4.5 billion USD, today this amount is known to exceed 20 billion USD. Health care services constitute an important part of the expenditures. ${ }^{3,13}$

Approximately 13.538 Syrian refugees presented to our hospital between 2013 and 2016 for examination, investigations and treatment. Of these patients, 555 received treatment on inpatient basis. The distribution of Syrian refugees among all patients admitted to our hospital increased gradually between 2013 and 2016. The number of Syrian refugees who received inpatient treatment increased significantly, especially in 2015 and 2016. Likewise, the number and rate of the Syrian refugees in EGD, BMA and liver biopsy, cerebral MRI and CT, rhythm holter and EEG examinations performed in our hospital between 2013 and 2016 increased gradually. While the amount of health care services delivered to Syrian refugees in our hospital was approximately $465.865 \mathrm{TL}$ in 2013; this amount increased to 1.575 .932 in $2014,2.303 .176$ TL in 2015 and 4.260 .110 TL in 2016. Health care services provided to Syrian refugees increased by about nine folds in 2016 compared to 2013. The reasons for the increase both in number and rate of Syrian refugees who presented to our hospital over the years can be explained as follows: First of all, Ankara where our hospital is located, is not a border province with Syria, thus the migration that started in 2011 was first felt at the border provinces and was then reflected on the other provinces of Turkey. Furthermore, since the Syrian refugees who settled in our country learned later that health care services provided for them were free of charge, the number of their visit to hospitals have increased by years. The registration of Syrian refugees has been carried out more regularly in recent years. The increased visits to pediatric hospitals by Syrian refugees in recent two or three years could be accepted normal because of the fact that the Syrian refugees who migrated to and settled in our country have children here. ${ }^{13,19}$ However, studies have found that the prevalence of preventive health care and vaccination was low among Syrian refugees. The reasons for this have been reported as financial concerns, language problems, and problems in the registration processes..$^{20,21}$ We believe that increasing the accessibility of primary health care services to Syrian refugees will reduce the frequency of presentations to tertiary healthcare institutions such as our hospital.

As the limitations of this study; it was conducted in a single center, and all interventional procedures and investigations performed in our hospital were not included. After citizenship numbers have been issued for Syrian refugees, the registration process has become more robust, so there may be shortcomings in records, especially before 2014 .

In conclusion, crisis in Syria is affecting neighboring countries in many issues. Countries that accept a large number of refugees such as Turkey need to reorganize their health policies accordingly. The Syrian refugee crisis should be governed at the global level with international organizations and countries to share the burden of refugee flows with the primary receiving countries. 
Sakarya Med J 2019;9(1):46-51

\section{References}

1. Türkiye Cumhuriyeti Başbakanlı, Afet ve Acil Durum Yönetimi Başkanlı̆̆ı, https://www. afad.gov.tr/upload/Node/3925/xfiles/syrian-refugees-in-turkey-2013_baski_30_12_2013_ tr.pdf 2013; [accessed 25.09.2018].

2. Syria Regional Refugee Response, Inter-agency Information Sharing Portal, http://data.unhcr.org/syrianrefugees/regional.php [accessed 16.08.2018].

3. Orhan O. Suriyeli Stğınmacıların Türkiye’ye Etkileri. Türkiye Ekonomik ve Sosyal Etüdler Vakfi Web sitesi. http://tesev.org.tr/wp-content/uploads/2015/11/Suriyeli_Siginmacilarin Turkiyeye_Etkileri.pdf [accessed 10.08.2018].

4. Zencir M, Davas A. Suriyeli Sı̆̆ınmacılar ve Sağllk Hizmetleri Raporu. Türk Tabipler Birliğ Web sitesi. https://www.ttb.org.tr/kutuphane/siginmacirpr.pdf [accessed 10.08.2018].

5. Korkmaz AÇ. Sığınmactların Sağlık ve Hemșirelik Hizmetlerine Yarattığı Sorunlar. Sağlık ve Hemşirelik Yönetimi Dergisi. 2014;1:37- 42.

6. Murshidi MM, Hijjawi MQ, Jeriesat S, Eltom A. Syrian refugees and Jordan's health sector. Lancet 2013;382:206-207

7. Doocy S, Lyles E, Akhu-Zaheya L, Burton A, Burnham G. Health service access and utilization among Syrian refugees in Jordan. Int J Equity Health. 2016;15:108.

8. Blanchet K, Fouad FM, Pherali T. Syrian refugees in Lebanon: the search for universal health coverage. Confl Health 2016;10:12.

9. Refaat MM, Mohanna K. Syrian refugees in Lebanon: facts and solutions. Lancet 2013;382:763-764

10. İçisleri Bakanlı̆̆ı Göç İdaresi Genel Müdürlüğü, http://www.goc.gov.tr/icerik3/gecici-korumanin-unsurlari_409_558_1095 [accessed 13.08.2018].

11. Ekmekci PE. Syrian Refugees, Health and Migration Legislation in Turkey. J Immigr Minor Health 2016;19:1434-1441.

12. Türk Tabipler Birliği, https://www.ttb.org.tr/kutuphane/siginmacilar_rpr.pdf, [accessed 13.08.2018]
13. Türkiye Cumhuriyeti Başbakanlı, Afet ve Acil Durum Yönetimi Başkanlı̆̆ı, https://www. afad.gov.tr/upload/Node/2373/files/Suriyeli_Siginmacilara_Yapilan_Yardimlar+6.pdf, [accessed 11.08.2018].

14. Doner P, Ozkara A, Kahveci R. Syrian refugees in Turkey: Numbers and emotions. Lance 2013;382:764.

15. Çevik S. Suriye’den Türkiye’ye göçün etkileri. Gümüşhane Üniversitesi Sağlık Bilimleri Dergisi 2016;5:80-83

16. Williams B, Cassar C, Siggers G, Taylor S. Medical and social issues of child refugees in Europe. Arch Dis Child 2016;101: 839-842

17. ISSOP Migration Working Group. ISSOP position statement on migrant child health. Child Care Health Dev 2017

18. Bilukha OO, Jayasekaran D, Burton A, Faender G, King'ori J, Amiri MA et al. Nutritional status of women and child refugees from Syria-Jordan, April-May 2014. MMWR Morb Mortal Wkly Rep 2014;63:638-639.

19. Karakaya E, Coşkun AM, Özerdoğan N, Yakıt E. Suriyeli Mülteci Kadınların Doğurganlık Özellikleri ve Etkileyen Faktörler: Kalitatif Bir Çalıșma. Uluslararası Sosyal Araştırmalar Dergisi 2017;10:417-428.

20. Avgün O, Gökdemir Ö, Bulut Ü, Yaprak S, Güldal D. Bir Toplum Sağ̆lğı Merkezi Örneğinde Sı̆̆ınmacı ve Mültecilere Verilen Birinci Basamak Sağltk Hizmetlerinin Değerlendirilmesi. TJFM\&PC 2016;10:6-12.

21. Kalkan O, Gülay M, Vatan İ, Engindeniz F, Bakış B, Mutlu M et al. Bursa İli Osmangazi İlçesinde İkamet Eden Suriyeli Göçmenlerin Temel Sağlık Durumlarının Değerlendirilmesi. In: 17. Ulusal Halk Sağlığı Kongresi 2014, Edirne. 